\title{
PENGATURAN PERUBAHAN GENRE MUSIK YANG DIUNGGAH MELALUI MEDIA SOSIAL BERDASARKAN UNDANG-UNDANG HAK CIPTA
}

\author{
Pebrianti Kumala Dewi, Fakultas Hukum Universitas Udayana, \\ E-mail: pebriantikumala@gmail.com \\ Ida Ayu Sukihana, Fakultas Hukum Universitas Udayana, E-mail: \\ ayu_sukihana@yahoo.com
}

doi: https://doi.org/10.24843/KS.2020.v09.i01.p11

\begin{abstract}
ABSTRAK
Studi ini bertujuan untuk menganalisa pengaturan perubahan genre musik yang diunggah melalui media sosial berdasarkan Undang-undang Nomor 28 Tahun 2014 tentang Hak Cipta serta untuk menganalisa dan memahami sanksi bagi pelaku yang pelanggar perubahan genre musik yang diunggah melalui media sosial. Penelitian yang digunakan yaitu dengan metode penelitian hukum normatif karena menggunakan pendekatan perundang-undangan dan pendekatan konsep. Kesimpulannya bahwa pengaturan tentang perubahan genre atau aliran musik belum secara tegas diatur pada Undang-Undang Nomor 28 Tahun 2014 Tentang Hak Cipta hanya dijelaskan, namun kegitatan mengaransemen suatu karya musik atau lagu ini terdapat dalam Undang-Undang Nomor 28 Tahun 2014 Tentang Hak Cipta yaitu dalam penjelasan Pasal 8 dan Pasal 9 serta sanksi bagi pelanggar yang mengubah genre music dan diunggah di sosial media ialah berupa sanksi pidana dan denda yang diatur dalam ketentuan Pasal 113 ayat 3 Undang-Undang Nomor 28 tahun 2018 Tentang Hak Cipta.
\end{abstract}

Kata Kunci: Perubahan Genre Musik, Media Sosial, Hak Cipta

\begin{abstract}
This study aims to analyze the regulation of changing music genres uploaded via social media "based on Law Number 28 of 2014 concerning Copyright" and to analyze and understand the sanctions for perpetrators who violate changes in music genres uploaded via social media. The research used is the normative legal research method because it "uses a statutory approach and a conceptual approach." The conclusion is that the regulation regarding changes in musical genres or genres has not been explicitly regulated in Law Number 28 of 2014 concerning Copyright is only explained, but the activities of arranging a musical work or song are contained in Law Number 28 of 2014 concerning Copyright, namely in the explanation of Article 8 and Article 9 as well as sanctions for violators who change the music genre and uploaded on social media are in the form of criminal sanctions and fines as regulated in the provisions of Article 113 paragraph 3 of Law Number 28 of 2018 concerning Copyright.
\end{abstract}

Keywords: Change in Music Genre, Social Media, Copyright

\section{Pendahuluan}

\subsection{Latar Belakang}

Dewasa ini, pengaruh media sosial cukup besar terutama dalam perkembangan teknologi komunikasi yang digunakan oleh kebanyakan remaja bahkan orang dewasa. Hak Kekayaan Intelektual juga bisa digunakan sebagai payung untuk menaungi segala bentuk dari hak eksklusif yang memiliki karakteristik masing-masing, ruang lingkup 
serta sejarah perkembangannya masing-masing. Perkembangan revolusi Industri telah menghasilkan perkembangan yang sangat pesat di bidang sains, teknologi dan budaya di mana perkembangan tersebut melahirkan jenis-jenis properti baru yang memerlukan perlindungan hukum. Kekayaan Intelektual lahir dari proses olah pikir manusia sebagai upaya untuk memenuhi kebutuhan hidup dalam masyarakat. Berbagai karya-karya intelektual yang baru dan unik sebagai proses olah pikir manusia diperlukan pengkajian yang lebih mendalam tentang konsep perlindungannya. Perlindungan terhadap Hak Kekayaan Intelektual dilakukan jika ide serta kemampuan intelektual manusia itu sudah diekspresikan serta diwujudkan.

Perlindungan hak kekayaan intelektual berakar dari negara maju yang memiliki pengaturan terkait hak kekayaan intelektual. Hak Kekayaan Intelektual umumnya dengan dihubungkan perlindungan ide dan informasi diterangkan yang nilai komersial dimiliki. Segala sesuatu berkembang dengan pesat dan mengubah berbagai aspek kehidupan dalam bermasyarakat. Salah satu perkembangan yang paling pesat terlihat adalah perkembangan dalam bidang teknologi. Perkembangan dalam bidang teknologi sangat terlihat dimasa ini memberi perubahan dalam kehidupan bermasyarakat. Teknologi yang berkembang pesat ini memiliki banyak sisi positif dalam kehidupan bermasyarakat.

Semenjak keikutsertaan Indonesia menjadi bagian dari World Trade Organization, Indonesia wajib melaksanakan seluruh kesepakatan World Trade Organization mengenai standar perdagangan internasional, yaitu salah satunya adalah mentaati Trade Related Aspects of Intellectual Property Rights (selanjutnya disebut perjanjian TRIPs) yaitu perjanjian dibidang kekayaan intelektual. ${ }^{1}$ Pasca meratifikasi perjanjian TRIPs, Indonesia dituntut untuk segera meratifikasi berbagai konvensi internasional mengenai Intellectual Property Rights serta memperbaharui perundang-undangan yang dengan dikaitkan Hak Kekayaan Intelektual maupun Hak Cipta. Sehingga pada tanggal 7 Mei 1997, Presiden Republik Indonesia mengeluarkan Keputusan Presiden yang mengesahkan berbagai konvensi internasional untuk memenuhi tuntutan perjanjian TRIPs. Presiden Republik Indonesia juga mengesahkan Undang-Undang yang memperbaharui Undang-Undang sebelumnya di bidang Hak Kekayaan Intelektual salah satunya yaitu Undang-Undang Nomor 12 Tahun 1997 tentang Hak Cipta yang kemudian mengalami perubahan menjadi Undang-Undang Nomor 19 Tahun 2002. Pemerintah Indonesia masih terus berupaya untuk mengkontruksi serta mengharmonisasikan hukum di bidang kekayaan intelektual sehingga UndangUndang Nomor 19 Tahun 2002 tentang Hak Cipta kembali mengalami perubahan menjadi Undang-Undang Nomor 28 Tahun 2014 tentang Hak Cipta

Hak Kekayaan Intelektual sangat penting memperoleh perlindungan, hal ini karena hak kekayaan intelektual merupakan hak yang timbul dari kekayaan yang diciptakan oleh kreativitas dan olah pikir intelektual manusia. Manusia terlahir dengan cipta dan karsa sehingga adanya kreativitas dalam diri manusia yang mampu melahirkan karya-karya intelektual. Karya-karya intelektual tersebut nilai ekonomi dimiliki dan bermanfaat bagi kehidupan manusia dalam meningkatkan kekayaan. Indonesia pada zaman dahulu tidak mengenal adanya perlindungan terkait hak kekayaan intelektual. Perlindungan hak kekayaan intelektual berakar dari negara maju yang memiliki pengaturan perundang-undangan terkait hak kekayaan intelektual.

1 Dharmawan, N. K. S. Wiryawan, dan I Wayan "Keberadaan dan Implikasi Prinsip MFN dan NT dalam Pengaturan Hak Kekayaan Intelektual Di Indonesia", Jurnal Ilmiah Magister Hukum Udayana Vol. 6, No. 2 (2014), 10. 
Pengaturan terkait hak kekayaan intelektual disepakati melalui berbagai konvensi Internasional. ${ }^{2}$ Salah satu kesenian yang umum di masyarakat salah satunya yaitu adalah musik. ${ }^{3}$ Karya cipta lagu atau musik sebagaimana dalam Undang-Undang Nomor 28 Tahun 2014 Tentang Hak Cipta dalam Pasal 40 Huruf d diartikan bahwa "karya cipta lagu atau musik merupakan sebagai ciptaan utuh yang hanya ada unsur lagu atau melodi, syair atau lirik juga aransemen, termasuk notasinya, artinya lagu atau musik tersebut merupakan suatu kesatuan dari sebuah karya cipta." 45 Hak Kekayaan Intelektual. Kegiatan yang kerap ditemui dijejaring media sosial adalah perubahan suatu genre musik. Dalam hal ini, mengaransemen musik dengan mengubah genre musik aslinya maka perlu adanya aturan mengenai perubahan genre musik yang diunggah melalui media sosial.

Musik merupakan suatu karya dibidang seni atau hiburan beserta aktivitas manusia. Musik terdiri dari suara-suara yang teratur. Beberapa musik dikelompokan ke suatu dalam genre yang genre dinamakan musik. ${ }^{6}$ Masyarakat sekarang ini terbiasa dengan media sosial, karena dengan adanya media sosial masyarakat dapat menggunggah apapun, salah satunya dengan menggunggah aransemen genre musik dimedia sosial. Akan tetapi banyak masyarakat yang mengaransemen suatu lagu atau musik dengan genre yang berbeda dari genre musik aslinya. Sebenarnya mengaransemen dengan mengubah genre dari suatu karya musik bukanlah suatu bentuk pelanggaran hukum apabila sudah adanya suatu kesepakatan antara kedua belah pihak, akan dapat dikatakan melanggar hukum apabila mengaransemen dilakukan tanpa ada kesepakatan kedua belah pihak. Sehubungan dengan ini maka penting untuk ditulis sebuah karya ilmiah yang berjudul "Pengaturan Perubahan Genre Musik Yang Diunggah Melalui Media Sosial Berdasarkan Undang-Undang Nomor 28 Tahun 2014 Hak Cipta"

Penelitian terdahulu dilakukan oleh Dewa Gede Jeremy Zefanya dan Anak Agung Sri Indrawati yang telah di terbitkan pada Jurnal Kertha Semaya pada Bulan November 2020 dengan Judul Kewajiban Pembayaran Royalti Terhadap Cover Lagu Milik Musisi Indonesia7. Adapun penelitian ini lebih menunjukkan terkait pengaturan pembayaran royalty serta akibat hukumnya apabilan tidak dilakukan pembayaran royalty bagi lagu milik musisi Indonesia yang telah dicover sedangkan penelitian yang dibuat oleh penulis lebih berfokus pada perubahan genre music yang diunggah di media sosial serta sanksi bagi pelaku perubahan genre music tersebut.

2 Yessiningrum, Winda Risna. "Perlindungan Hukum Indikasi Geografis sebagai Bagian dari Hak Kekayaan Intelektual." Jurnal IUSY Kajian Hukum dan Keadilan 3, no. 1 (2015).

3 Wicaksono, Annastya Joko Sinar. "Proses Kreatif Penciptaan Musik Dakwah Islam Berjudul Seruan Perubahan Karya Grup Band Melawan Bungkam." PhD diss., Institut Seni Indonesia Yogyakarta, 2017.

4 Miladiyanto, Sulthon. "Royalti Lagu/Musik Untuk Kepentingan Komersial Dalam Upaya Perlindungan Hak Cipta Lagu/Musik." Rechtideet 10, no. 1 (2015): 1-17.

5 Albar, Ahmad Faldi, Rohaini Rohaini, and Diane Eka Rusmawati. "PERLINDUNGAN HUKUM PENGGUNAAN MUSIK SEBAGAI LATAR DALAM YOUTUBE MENURUTUNDANG-UNDANG HAK CIPTA." Pactum Law Journal 1, no. 04 (2018): 321-335.

6 Anthasenna, I. D. G., Wayan Firdaus Mahmudy, and M. Tanzil Furqon. "Sistem Identifikasi Genre Musik dengan Metode Ekstraksi Fitur FFT dan Metode Klasifikasi Linear Discriminant Analysis Beserta Similarity Measure." Universitas Brawijaya (2014).

7 Zefanya, Dewa Gede Jeremy, and Anak Agung Sri Indrawati. "KEWAJIBAN PEMBAYARAN ROYALTI TERHADAP COVER LAGU MILIK MUSISI INDONESIA." Kertha Semaya: Journal Ilmu Hukum 8, no. 12: 1908-1917. 


\subsection{Rumusan Masalah}

Berdasarkan uraian pada latar belakang masalah tersebut, dapat dirumuskan beberapa permasalahan yang menarik untuk dikaji, sebagai berikut:

1. Bagaimana pengaturan perubahan genre musik yang diunggah melalui media sosial berdasarkan Undang-Undang Nomor 28 tahun 2014 tentang Hak Cipta?

2. Bagaimana sanksi bagi pelanggar yang mengubah genre musik yang diunggah melalui media sosial?

\subsection{Tujuan Penulisan}

Penulisan jurnal ilmiah ini memiliki tujuan untuk mengetahui bagaimana pengaturan perubahan genre musik yang diunggah melalui media sosial berdasarkan Undang-undang Nomor 28 Tahun 2014 tentang Hak Cipta serta untuk mengetahui bagaimana sanksi bagi pelanggar perubahan genre musik yang diunggah melalui media sosial.

\section{Metode Penelitian}

Studi ini menggunakan metode penelitian hukum normatif, yang mengkaji dan menganalisis pokok permasalahan dengan substansi Peraturan Perundang-Undangan. Dalam menunjang proses penelitian jenis pendekatan yang digunakan ialah pendekatan perundang-undangan (Statue approach) serta pendekatan konseptual (Conceptual approach) ${ }^{8}$, yang pada konteksnya dilakukan dengan menelaah isu hukum yang hendak dijawab dengan semua undang-undang dan semua regulasinya yang bersangkutan. Analisis dalam studi ini menggunakan teknik deskripsi pada bahan hukum primer dan bahan hukum sekunder berupa buku-buku literatur.

\section{Hasil dan Pembahasan}

3.1 Pengaturan Perubahan Genre Musik yang Diunggah Melalui Media Sosial Berdasarkan Undang-Undang Nomor 28 tahun 2014 Tentang Hak Cipta

Kreativitas dalam diri manusia yang mampu melahirkan karya-karya intelektual. Karya-karya intelektual tersebut nilai ekonomi dimiliki dan bermanfaat bagi kehidupan manusia dalam meningkatkan kekayaan. Indonesia pada zaman dahulu tidak mengenal adanya perlindungan terkait hak kekayaan intelektual. Mengingat pesatnya perkembangan musik di Indonesia memungkinkan seseorang untuk mempunyai pustaka musik yang sangat banyak. Musik yang ingin dinikmati akan disesuaikan dengan suasana hati ataupun keadaan dari penikmat musik itu sendiri, sehingga ketika pustaka musiknya sangat besar kemungkinan akan membuat seseorang merasa kesulitan dalam memilih genre usik yang diinginkan pada saat yang tepat. Sehingga seseorang cenderung mengaransemen genre musik sendiri dan diunggahnya ke media sosial.

Aransemen genre musik adalah hasil dari reproduksi atau dibawakannya ulang sebuah lagu atau musik yang pernah direkam sebelumnya dan dibawakan penyanyi

8 Soekanto, Soerjono, and Sri Mamudji. Penelitian hukum normatif: Suatu tinjauan singkat. (Jakarta: RajaGrafindo Persada, 2001), 14. 
lain atau penciptanya dengan mengubah tampilan berbeda dari aslinya. ${ }^{9}$ Terkadang, mengaransemen genre sebuah lagu atau musik ini akan lebih memiliki daya tarik yang kuat. Kebanyakan orang menjadi lebih memilih karya yang telah diaransemen saja dibandingkan lagu atau musik aslinya karena genre musik yang telah diaransemen sesuai dengan peminat hati dan mengunggahnya ke media sosial dan dipertontonkan ke banyak orang. Kegiatan yang kerap ditemui dijejaring media sosial adalah perubahan suatu genre musik. Dalam hal ini, mengaransemen musik dengan mengubah genre musik aslinya maka perlu adanya aturan mengenai perubahan genre musik yang diunggah melalui media sosial.

Lagu termasuk dalam ranah Hak Kekayaan Intelektual yang dilindungi sebagaimana diatur dalam Undang-Undang Nomor 28 Tahun 2014 tentang Hak Cipta dalam Pasal 58 huruf d yaitu Perlindungan Hak Cipta atas Ciptaan lagu atau musik dengan atau tanpa teks. ${ }^{10}$ Perlindungan hak kekayaan intelektual berakar dari negara maju yang memiliki pengaturan perundang-undangan terkait hak kekayaan intelektual. Hak Kekayaan Intelektual umumnya dengan dihubungkan perlindungan ide dan informasi diterangkan yang nilai komersial dimiliki. Segala sesuatu berkembang dengan pesat dan mengubah berbagai aspek kehidupan dalam bermasyarakat. Salah satu perkembangan yang paling pesat terlihat adalah perkembangan dalam genre musik. Perkembangan dalam genre musik sangat terlihat dimasa ini memberi perubahan dalam kehidupan bermasyarakat. Teknologi yang berkembang pesat ini memiliki banyak sisi positif dalam kehidupan bermasyarakat.

Hak Kekayaan Intelektual sangat penting perlindungan diperoleh, hal ini karena hak kekayaan intelektual merupakan hak timbul yang dari kekayaan yang diciptakan oleh kreativitas dan olah pikir intelektual manusia. Manusia terlahir dengan cipta dan karsa sehingga adanya kreativitas dalam diri manusia yang mampu melahirkan karyakarya intelektual. Karya-karya intelektual tersebut nilai ekonomi dimiliki dan bermanfaat bagi kehidupan manusia dalam meningkatkan kekayaan. Indonesia pada zaman dahulu tidak mengenal adanya perlindungan terkait hak kekayaan intelektual. Perlindungan hak kekayaan intelektual berakar dari negara maju yang memiliki pengaturan perundang-undangan terkait hak kekayaan intelektual. Pengaturan terkait hak kekayaan intelektual disepakati melalui berbagai konvensi Internasional.

Lahirnya media sosial yaitu akibat perkembangan teknologi yang sangat cepat dan pesat yang masyarakat mudah untuk informasi ditukar dengan internet digunakan yang menjadi mediumnya. Salah satunya yaitu banyak orang yang menggukanan media sosial untuk mengunggah hasil karya yang telah dibuatnya dengan bantuan internet. Internet adalah salah satu cara baru yang mudah untuk informasi disalurkan dikalangan masyarakat hadir media sosial sehingga dan sangat cepat mengubah paradigma berkomunikasi di masyarakat sampai saat ini. ${ }^{11}$

Konsep Hak Kekayaan Intelektual adalah suatu dari penghargaan hasil bentuk kreatifitas dari manusia baik itu bentuk dalam penemuan ataupun hasil karya cipta dan juga seni. ${ }^{12}$ Dalam Undang-Undang Nomor 28 Tahun 2014 Tentang Hak Cipta

9 Setiaji, Denis. "Tinjauan Karakteristik Dangdut Koplo Sebagai Perkembangan Genre Musik Dangdut." Jurnal Hande 1, no. 01 (2017).

10 Kusno, Habi. "Perlindungan Hukum Hak Cipta Terhadap Pencipta Lagu yang Diunduh Melalui Internet." FIAT JUSTISIAT: Jurnal Ilmu Hukum 10, no. 3 (2016).

11 Dewi, Anak Agung Mirah Satria. "Perlindungan Hukum Hak Cipta Terhadap Cover Version Lagu Di Youtube." .Udayana Master Law Journal 6, no. 4 (2017).

12 Roisah, Kholis. Konsep hukum hak kekayaan intelektual: sejarah, pengertian dan filosofi pengakuan HKI dari masa ke masa. (Malang: Setara Press, 2015), 2. 
dalam Pasal 1 angka 1, mengidentifikasikan bahwa Hak Cipta adalah "hak eksklusif Pencipta yang timbul secara otomatis berdasarkan prinsip deklaratif setelah suatu ciptaan diwujudkan dalam bentuk nyata tanpa mengurangi pembatasan sesuai dengan ketentuan peraturan perundang-undangan."

Undang-Undang Nomor 28 Tahun 2014 tentang Hak Cipta dalam penjelasan Pasal 4 memberikan definisi mengenai hak eksklusif. Menurut penjelasan Pasal 4 tersebut hak eksklusif adalah hak yang hanya diperuntukkan bagi Pencipta, sehingga tidak ada pihak lain yang dapat memanfaatkan hak tersebut tanpa izin Pencipta. Hak moral diatur dalam Undang-Undang Nomor 28 Tahun 2014 Tentang Hak Cipta dalam Pasal 5 ayat (1). Hak ekonomi dari suatu hak cipta sajalah yang hanya bisa beralih atau dialihkan kepada orang lain dari hak cipta, sementara dengan hak moralnya tidak dapat dipisahkan dari diri Penciptanya. Seperti yang dijelaskan dalam UndangUndang Nomor 28 Tahun 2014 Tentang hak cipta yaitu dalam Pasal 4 dan Pasal 5 Undang- bahwa setiap ciptaan pasti memiliki hak ekonomi dan hak moral yang mana berarti ciptaan tersebut wajib dilindungi oleh Undang-Undang.

Pasal 40 ayat (1) huruf d, lagu dan/atau musik diartikan sebagai karya yang bersifat utuh, sekalipun terdiri atas unsur lagu atau melodi, syair atau lirik, dan aransemennya termasuk notasi. Membawakan ulang suatu karya cipta lagu dan/atau musik yang sebelumnya pernah dibawakan oleh seorang Musisi selaku Pencipta atau Pemegang Hak Cipta dari musik merupakan salah satu bentuk kegiatan pengaransemenan sebagaimana termuat di dalam Undang-Undang Nomor 28 Tahun 2014 Tentang Hak Cipta dalam Pasal 9 ayat (1). ${ }^{13}$

Walaupun dalam Undang - Undang Hak Cipta bahwa disebutkan perlindungan hukum hak cipta timbul secara otomatis atau tanpa didaftarkan, namun apabila suatu karya cipta didaftarkan terlebih dahulu maka akan lebih menguntungkan pencipta atau pemegang hak cipta karena dengan dilakukannya pendaftaran akan memberikan bukti formal dan akan memberikan kepastian hukum bahwa ciptaan tersebut benar pencipta atau pemegang hak cipta oleh dimiliki. Sehingga apabila terjadi pelanggaran atau pembajakan karya cipta, si pencipta akan dibuktikan mudah lebih dan tuntutan kepada diajukan orang melanggar hak cipta karna telah memiliki bukti formal hasil dari pendaftaran.

Perlindungan terhadap Hak Cipta pada dasarnya memang bersifat otomatis diperoleh pencipta sejak ciptaan lahir dan proses pencatatan dilalui tidak harus, namun jika pencatatan terhadap suatu ciptaan itu dilakukan maka lebih akan baik dan diuntungkan lebih. Pencatatan bukanlah untuk melahirkan perlindungan tetapi dengan pencatatan maka pencipta akan mendapatkan bukti formal berupa sertifikat Hak Cipta, yang dapat digunakan sebagai bukti awal apabila terjadi sengketa terhadap ciptaan yang dicatatkan tersebut. Ciptaan yang tidak dicatatkan tetap diakui dan dilindungi, namun tidak dapat disangkal apabila terjadi sengketa di kemudian hari akan sangat sulit untuk pembuktiannya karena tidak memiliki bukti formal sebagai pemilik Hak Cipta. Sehingga pencatatan sangat dianjurkan bagi pencipta untuk membuktikan keabsahan haknya.

Ciptaan-ciptaan yang mendapatkan perlindungan hak cipta harus memiliki unsur keaslian yaitu terdapat kreatifitas pencipta serta tidak merupakan hasil tiruan

13 Mashdurohatun, Anis. "Problematika Perlindungan Hak Cipta di Indonesia." .Yustisiat Jurnal Hukum 1, no. 1 (2012). 
dan didalamnya tercermin refleksi diri dari penciptanya. ${ }^{14}$ Pengaturan tentang perubahan genre atau aliran musik secara belum tegas diatur dalam Undang-Undang Nomor 28 Tahun 2014 Tentang Hak Cipta, namun untuk mengaransemen atau mengubah genre musik lain atau kegitatan mengaransemen suatu karya musik atau lagu ini terdapat dalam Undang-Undang Hak Cipta dalam penjelasan Pasal 9 ayat (1).

\subsection{Sanksi Bagi Pelanggar yang Merubah Genre Musik yang Diunggah Melalui Media Sosial}

Permasalahan yang terjadi masa kini adalah terkadang orang yang melakukan kegiatan mengaransemen genre sebuah musik atau lagu justru menjadi lebih terkenal daripada penyanyi asli lagu tersebut apalagi kemudian diunggahnya kedalam media sosial, sehingga sering terjadi sengketa diantara pemilik lagu atau musik asli dengan orang yang mengcover lagu. Hal ini dikarenakan pemilik atau pencipta musik atau lagu asli yang biasanya juga pemilik hak terkait merasa dirugikan karena karyanya lebih dikenal karena orang lain bukan karena karya yang mereka buat.

Perkembangan dari suatu pelanggaran aktivitas hak cipta ini dipengaruhi oleh adanya beberapa faktor. Kurangnya tingkatan pemahaman dari masyarakat mengenai arti dan fungsi tentang hak cipta, sikap dan keinginan keuntungan untuk diperoleh mudah dengan yang cara digunakan, belum cukup lagi ditambah dengan ini adalah faktor yang dapat memperoleh perhatian. ${ }^{15}$ Aransemen genre musik adalah hasil dari reproduksi atau dibawakannya ulang sebuah lagu atau musik yang pernah direkam sebelumnya dan dibawakan penyanyi lain atau penciptanya dengan mengubah tampilan berbeda dari aslinya. Terkadang, mengaransemen genre sebuah lagu atau musik ini akan lebih memiliki daya tarik yang kuat. Kebanyakan orang menjadi lebih memilih karya yang telah diaransemen saja dibandingkan lagu atau musik aslinya karena genre musik yang telah diaransemen sesuai dengan peminat hati dan mengunggahnya ke media sosial dan dipertontonkan ke banyak orang.

Pelanggaran merupakan suatu perbuatan yang melanggar hak cipta diantaranya seperti penggunaan hak cipta, hak pribadi milik pencipta, tanpa izin dan pendaftaran hak cipta oleh orang lain yang bukan pemegang hak cipta. Pelanggaran tersebut salah satunya adalah pelanggaran hak cipta dengan mengaransemen sebuah genre musik yang mana itu sudah menjadi perhatian melalui perkembangan media sosial yang sangatlah akrab di dalam kehidupan masyarakat. Berbicara mengenai pelanggaran dari suatu hak cipta adalah berkaitan dengan hak moral dan hak ekonominya. ${ }^{16}$

Perbuatan yang dapat dikatakan melanggar hak moral pencipta musik atau lagu adalah apabila tanpa ijin, sebagaimana hak moral terdapat dalam Undang-Undang Nomor 28 Tahun 2014 Tentang Hak Cipta yaitu dalam Pasal 5 sampai dengan Pasal 7. Perbuatan yang melanggar hak ekonomi yaitu perbuatan tanpa ijin, perbuatan memperbanyak suatu karya cipta tanpa ijin, sebagaimana terdapat dalam Undang-

14 Maharani, Desak Komang Lina, and I. Gusti Ngurah Parwata. "PERLINDUNGAN HAK CIPTA TERHADAP PENGGUNAAN LAGU SEBAGAI SUARA LATAR VIDEO DI SITUS YOUTUBE." “Kertha Semaya: Journal Ilmu Hukum 7, no. 10 (2019): 1-14."

15 Syamsudin, M. "Nilai-Nilai Karya Cipta dan Problematik Perlindungan Hukumnya." "Jurnal Hukum Ius Quiat Iustum 8, no. 16 (2001): 121-136."

16 Assa, Marybella Natasha. "Upaya Perlindungan Hukum Terhadap Hak Cipta Lagu dan Musik di Internet Menurut Undang-Undang Nomor 28 Tahun 2014." Lexy Privatum 4, no. 1 (2016). 
Undang Nomor 28 Tahun 2014 Tentang Hak Cipta dalam Pasal 8 sampai Pasal 11. Halhal itu tentu secara langsung maupun tidak langsung dapat merugikan pencipta.

Undang-Undang Nomor 28 Tahun 2014 Tentang Hak Cipta tidak mengatur mengenai pelanggaran dalam mengaransemen genre musik dan/atau lagu akan tetapi hanya mengatur tentang perubahan yang dijelaskan dalam Undang-Undang Nomor 28 Tahun 2014 Tentang Hak Cipta dalam Pasal 8. Dalam Undang-Undang Nomor 28 tahun 2014 Tentang Hak Cipta dalam Pasal 8 menyatakan bahwa "hak ekonomi merupakan Pemegang Hak cipta untuk atas Ciptaan hak ekslusif pencipta atau mendpatkan manfaat ekonomi. Hak moral, sebagaimana hak moral ini terpisah dari hak ekonomi."17

Suatu karya jika diciptakan secara khas oleh seseorang akan menjadi suatu hak kekayaan intelektual baginya. Pengaturan tentang perubahan genre atau aliran secara belum tegas diatur dalam Undang-Undang Nomor 28 Tahun 2014 tentang Hak Cipta, namun untuk mengaransemen atau mengubah genre musik lain haruslah dengan ijin dari pencipta musik tersebut. Pelanggaran yang pertama yaitu terhadap hak ekonomi pencipta dapat dikenakan suatu sanksi pidana yaitu dalam Undang-Undang Nomor 28 Tahun 2014 Tentang Hak Cipta dalam Pasal 113 ayat (3) yang menjelaskan bahwa:

"Setiap Orang yang dengan tanpa hak dan/atau tanpa izin Pencipta atau pemegang Hak Cipta melakukan pelanggaran hak ekonomi Pencipta sebagaimana dimaksud dalam Pasal 9 ayat (1) huruf a, huruf b, huruf e, dan/atau huruf g untuk Penggunaan Secara Komersial dipidana dengan pidana penjara paling lama 4 (empat) tahun dan/atau pidana denda paling banyak Rp1.000.000.000,00 (satu miliar rupiah)".

Penggunaan kembali lagu atau musik tersebut tidak untuk kepentingan komersial atau tidak mendapat keuntungan yang melanggar hak ekonomi dari pencipta maka hukuman pidana diatas tidak berlaku bagi pelaku perubah genre musik. Pada dasarnya dengan mengaransemen ulang suatu genre karya cipta lagu dan/atau musik yang kemudian diunggah ke jejaring media sosial dengan tanpa adanya ijin bukan merupakan pelanggaran apabila tetap mencantumkan hak moral dari lagu dan/atau musik tersebut yang terdiri atas nama Pencipta dan judul dari lagu dan/atau musik itu. ${ }^{18}$

\section{Kesimpulan}

Pengaturan tentang perubahan genre atau aliran musik belum secara tegas diatur dalam Undang-Undang Nomor 28 Tahun 2014 Tentang Hak Cipta, akan tetapi untuk mengaransemen atau mengubah genre musik lain atau kegitatan mengaransemen suatu karya musik atau lagu ini terdapat dalam Undang-Undang Nomor 28 tahun 2018 Tentang Hak Cipta dalam penjelasan Pasal 9 ayat (1) serta terkait sanksi bagi pelanggar yang mengubah genre music dan diunggah di sosial media diatur dalam ketentuan Pasal 113 ayat 3 Undang-Undang Nomor 28 tahun 2018 Tentang Hak Cipta yaitu "Setiap Orang yang dengan tanpa hak dan/atau tanpa izin Pencipta atau pemegang Hak Cipta melakukan pelanggaran hak ekonomi Pencipta sebagaimana dimaksud dalam Pasal 9 ayat (1) huruf a, huruf b, huruf e, dan/atau huruf g untuk

17 Johani, Sang Ayu Nyoman, I. W. Wiryawan, and I. N. Mudana. "Pelaksanaan Perlindungan Hak Cipta Dari Patung Akar Bambu Di Desa Tembuku Kabupaten Bangli." "Kertha Semaya: Journal Ilmu Hukum 7, no. 8 (2019): 1-14."

18 Fadhila, G., and U. Sudjana. "Perlindungan karya cipta lagu dan/atau musik yang dinyanyikan ulang." Jurnal Hukum Kenotariatan Dan 1, no. 2 (2018): 222-235. 
Penggunaan Secara Komersial dipidana dengan pidana penjara paling lama 4 (empat) tahun dan/atau pidana denda paling banyak Rp1.000.000.000,00 (satu miliar rupiah)".

Diharapkan masyarakat ikut serta dalam penegakan perlindungan hukum hak cipta. Hendaknya ada penyempurnaan hukum agar dapat menciptakan hukum yang dapat mengikuti perkembangan yang ada. Terutama dalam penegakan hukum hak cipta tentang menggunakan lagu orang lain dan mengunggahnya ke media sosial. Hukum hak cipta harus ditinjau dan disempurnakan secara teratur pengaturannya. Pemerintah juga diharapkan untuk membuat sosialisasi atau seminar kepada masyarakat umum terutama pada anak-anak muda yang saat ini selalu bersentuhan dengan media internet, sosialisasi tentang bagaimana menghargai hasil karya cipta yang di kerjakan oleh para pekerja seni, sehingga tingkat pelanggaran hak cipta akan menurun dan masyarakat dapat hidup sejahtera.

\section{DAFTAR PUSTAKA}

\section{Buku:}

Roisah, Kholis. Konsep hukum hak kekayaan intelektual: sejarah, pengertian dan filosofi pengakuan HKI dari masa ke masa. (Malang: Setara Press, 2015).

Soekanto, Soerjono, and Sri Mamudji. Penelitian hukum normatif: Suatu tinjauan singkat. (Jakarta: RajaGrafindo Persada, 2001).

\section{Jurnal Ilmiah :}

Albar, Ahmad Faldi, Rohaini Rohaini, and Diane Eka Rusmawati. "PERLINDUNGAN HUKUM PENGGUNAAN MUSIK SEBAGAI LATAR DALAM YOUTUBE MENURUT UNDANG-UNDANG HAK CIPTA." Pactum Law Journal 1, no. 04 (2018): 321-335..

Anthasenna, I. D. G., Wayan Firdaus Mahmudy, and M. Tanzil Furqon. "Sistem Identifikasi Genre Musik dengan Metode Ekstraksi Fitur FFT dan Metode Klasifikasi Linear Discriminant Analysis Beserta Similarity Measure." Universitas Brawijaya (2014).

Assa, Marybella Natasha. "Upaya Perlindungan Hukum Terhadap Hak Cipta Lagu dan Musik di Internet Menurut Undang-Undang Nomor 28 Tahun 2014." Lexy Privatum 4, no. 1 (2016).

Dewi, Anak Agung Mirah Satria. "Perlindungan Hukum Hak Cipta Terhadap Cover Version Lagu Di Youtube." Udayana Master Law Journal 6, no. 4 (2017).

Dharmawan, N. K. S. Wiryawan, dan I Wayan "Keberadaan dan Implikasi Prinsip MFN dan NT dalam Pengaturan Hak Kekayaan Intelektual Di Indonesia", Jurnal Ilmiah Magister Hukum Udayana Vol. 6, No. 2 (2014).

Fadhila, G., and U. Sudjana. "Perlindungan karya cipta lagu dan/atau musik yang dinyanyikan ulang." Jurnal Hukum Kenotariatan Dan 1, no. 2 (2018): 222-235.

Johani, Sang Ayu Nyoman, I. W. Wiryawan, and I. N. Mudana. "Pelaksanaan Perlindungan Hak Cipta Dari Patung Akar Bambu Di Desa Tembuku Kabupaten Bangli." “Kertha Semaya: Journal Ilmu Hukum 7, no. 8 (2019): 1-14.

Kusno, Habi. "Perlindungan Hukum Hak Cipta Terhadap Pencipta Lagu yang Diunduh Melalui Internet." FIAT JUSTISIAT: Jurnal Ilmu Hukum 10, no. 3 (2016).

Maharani, Desak Komang Lina, and I. Gusti Ngurah Parwata. "PERLINDUNGAN HAK CIPTA TERHADAP PENGGUNAAN LAGU SEBAGAI SUARA LATAR 
VIDEO DI SITUS YOUTUBE." "Kertha Semaya: Journal Ilmu Hukum 7, no. 10 (2019): 1-14."

Mashdurohatun, Anis. "Problematika Perlindungan Hak Cipta di Indonesia." Yustisiat Jurnal Hukum 1, no. 1 (2012).

Miladiyanto, Sulthon. "Royalti Lagu/Musik Untuk Kepentingan Komersial Dalam Upaya Perlindungan Hak Cipta Lagu/Musik." Rechtideet 10, no. 1 (2015): 1-17

Setiaji, Denis. "Tinjauan Karakteristik Dangdut Koplo Sebagai Perkembangan Genre Musik Dangdut." Jurnal Hande 1, no. 01 (2017).

Syamsudin, M. "Nilai-Nilai Karya Cipta dan Problematik Perlindungan Hukumnya." Jurnal Hukum Ius Quiat Iustum 8, no. 16 (2001): 121-136.

Wicaksono, Annastya Joko Sinar. "Proses Kreatif Penciptaan Musik Dakwah Islam Berjudul Seruan Perubahan Karya Grup Band Melawan Bungkam." PhD diss., Institut Seni Indonesia Yogyakarta, 2017.

Yessiningrum, Winda Risna. "Perlindungan Hukum Indikasi Geografis sebagai Bagian dari Hak Kekayaan Intelektual." Jurnal IUST Kajian Hukum dan Keadilan 3, no. 1 (2015).

Zefanya, Dewa Gede Jeremy, and Anak Agung Sri Indrawati. "KEWAJIBAN PEMBAYARAN ROYALTI TERHADAP COVER LAGU MILIK MUSISI INDONESIA." Kertha Semaya: Journal Ilmu Hukum 8, no. 12: 1908-1917.

\section{Peraturan perundang-undangan :}

Undang-Undang Dasar Negara Republik Indonesia Tahun 1945.

Undang-Undang Nomor 28 Tahun 2014 Tentang Hak Cipta. 